\title{
Economic Analysis of the Determinants of the Adoption of Water and Soil Conservation Techniques in Burkina Faso: Case of Cotton Producers in the Province of Bam
}

\author{
Dissani Badoubatoba Mathieu, Sanmang Wu*, Goetswang Kealeboga Fredah \\ School of Economics and Management, China University of Geosciences, Beijing, China \\ Email: *wusanmang@sina.com
}

How to cite this paper: Mathieu, D.B., Wu, S.M. and Fredah, G.K. (2019) Economic Analysis of the Determinants of the Adoption of Water and Soil Conservation Techniques in Burkina Faso: Case of Cotton Producers in the Province of Bam. Journal of Environmental Protection, 10, 1213-1223. https://doi.org/10.4236/jep.2019.1010072

Received: July 9, 2019

Accepted: September 24, 2019

Published: September 27, 2019

Copyright $\odot 2019$ by author(s) and Scientific Research Publishing Inc. This work is licensed under the Creative Commons Attribution International License (CC BY 4.0).

http://creativecommons.org/licenses/by/4.0/

c) (i) Open Access

\begin{abstract}
Soil degradation is a major problem in the Sudano-Sahelian zone of Burkina Faso. To maintain or improve soil productivity levels and limit Water losses, especially with rainfall variability, adaptation strategies have been developed that focus on water and Soil Conservation techniques (WSC). Although their agronomic benefits have been proven, adoption rates for these techniques are generally low, particularly among cotton farmers in Bam province. The main objective of this study is to identify the socioeconomic and institutional determinants of the adoption of WSC among cotton farmers in Bam. The data used for our study were collected as part of the Semi-Arid Resilience Promotion Project (SARP) from cotton producers in the province. A probit model was used to analyze the factors that determine the adoption of WSC in Bam cotton producers. The results show that variables such as early warning, group membership, smartphone ownership, and cotton income positively influence the likelihood of producers adopting WSC techniques. On the other hand, technical assistance and access to the pesticide have a negative influence on the adoption of WSC by Bam cotton producers.
\end{abstract}

\section{Keywords}

WSC Adoption, Probit, Cotton, Climate Change, Bam

\section{Introduction}

Burkina Faso is located in the semi-arid sub-region of West Africa, called the Sahel. This landlocked country's area is $274,200 \mathrm{~km}^{2}$ and the population was estimated at 13,575,000 in mid-2004 (Population Reference Bureau). Roughly 33\% 
of the area is devoted to agricultural production [1] [2]. The country is flat and the relief consists of a vast plateau with $749 \mathrm{~m}$ as the highest point. Like other countries in the Sahel, Burkina Faso has been affected by these disturbances of the rainfall regime (devastating floods, heavy rains). The climatic conditions delineating the extent of agricultural practices and the changes in rainfall patterns have a definite impact on agricultural ecosystems and average yields. Their impacts on agriculture are inevitable and raise the issue of adaptation, which is an emergency for Burkina Faso in terms of its vulnerability to climate variability. In the Sudano-Sahelian cotton zone of Cameroon, agriculture is perceived as a major factor of environmental degradation and more particularly as promoting soil erosion which is a phenomenon characterized by the detachment of soil particles from their initial location. Then their transport and deposition by water or wind have the direct consequence of soil degradation [2] [3]. Each year, 75 billion metric tons of soil is displaced on the earth's surface by wind and water erosion. Similarly, $50 \%$ of the Earth's surface is affected by anthropogenic processes of soil degradation.

Every year, 6 to 7 million hectares of agricultural land in the world is rendered unproductive by erosion [4]. Faced with this situation, the scientific community, the states, and the farmers have joined forces to develop and implement various complementary strategies (Rhodes, 2014) to adapt to climate change. Climate adaptation refers to changes in ecological, social and economic systems in response to climatic stimuli (IPCC, 2001 Climate Change Outcomes: Consequences, Adaptations, and Vulnerability, 2001) [5]. The literature on climate change reveals that there are many types of adaptation measures in agriculture. On farms, farmers and researchers used soil and water conservation techniques, improved crop varieties, modified planting dates, crop diversification, funds and seasonal forecasts [3].

With large agricultural areas of about 9 million hectares (one-third of the country), whose estimated area for the 2012-2013 crop year is 5,779,046 hectares [5]. They are occupied by the cultivation of cereals, rents, and food. According to (INERA, 2000), about $24 \%$ of arable land in Burkina Faso is highly degraded and threatens to affect the quality of the natural environment and food security in the medium and long term. Soil degradation is one of the major problems [6] [7].

The essence of this study, therefore, is to develop a better understanding of the drivers of the adoption of water and soil conservation technologies. This will enable government and stakeholders to design policies that are geared towards improving the adoption of the technologies. The analysis is expected to provide in-depth knowledge of technology adoption and the role played by a farmer, farm and institutional factors in adoption.

The rest of the paper is organized as follows: Section 2 presents a review of related literature. While Section 3 outlines the methodology, Section 4 discusses the findings of the study. Section 5 concludes the study with recommendations. 


\section{Literature Review on the Empirical Determinants of Adoption}

Many studies have been conducted on the adoption of environmental resource management technologies in general and water and soil conservation technologies in particular. From these studies, several sensible factors influenced the adoption of these technologies were listed. According to neoclassical theory, farmers adopt new technologies if they bring them net economic benefits [8]. However, it is established that the reason why farmers adopt new technology goes beyond the neoclassical theory [4]. Many studies have analyzed the variables that influence the adoption of new technologies in the agricultural sector, among others [4] [9] [10] [11]. Variables affecting the adoption of new technology were classified into the following groups: human capital or socio-personal variables, structural factors and social capital [4].

\section{Methodology}

\subsection{Study Area and Data Collection (Figure 1)}

The data used in this study are those of the survey conducted in 2017 in arid and dryland areas of Burkina Faso, as part of the Semi-Arid Zone Resilience Promotion Project (SARP). The objective of the project is to see how climate change affects the economic performance of private actors in these areas. In the implementation of research strategies, the researchers involved in this project are firmly convinced that climate change is negatively affecting economic returns in these areas, but they believe that it is also possible to identify new opportunities related to climate variability. Recognizing that the richest and most successful private actors are already implementing strategies to adapt to climate change, our work in this study is to determine the socioeconomic and institutional factors involved in the adoption of WSC techniques.

\subsection{Specification and Justification of the Choice of the Probit Model}

There are many studies on the adoption of water and soil conservation technologies that have used econometric models. Many authors agree to define the word model as the simplified representation of a real phenomenon. In the econometric literature, three models have been used frequently to analyze the adoption of new technologies: 1) models with linear probability, 2) logistic function (Logit) and 3) functions with normal density (probit) [2] [12] [13]. These models use binary choice variables as the dependent variable [5]. The Tobit model is used when information about the adoption or not of technology and better if the information on the level of use of the technology is known. The Probit and Logit models have similar characteristics except that the Logit model is based on the logistic law of probability distribution while the Probit model is based on the normal distribution. 


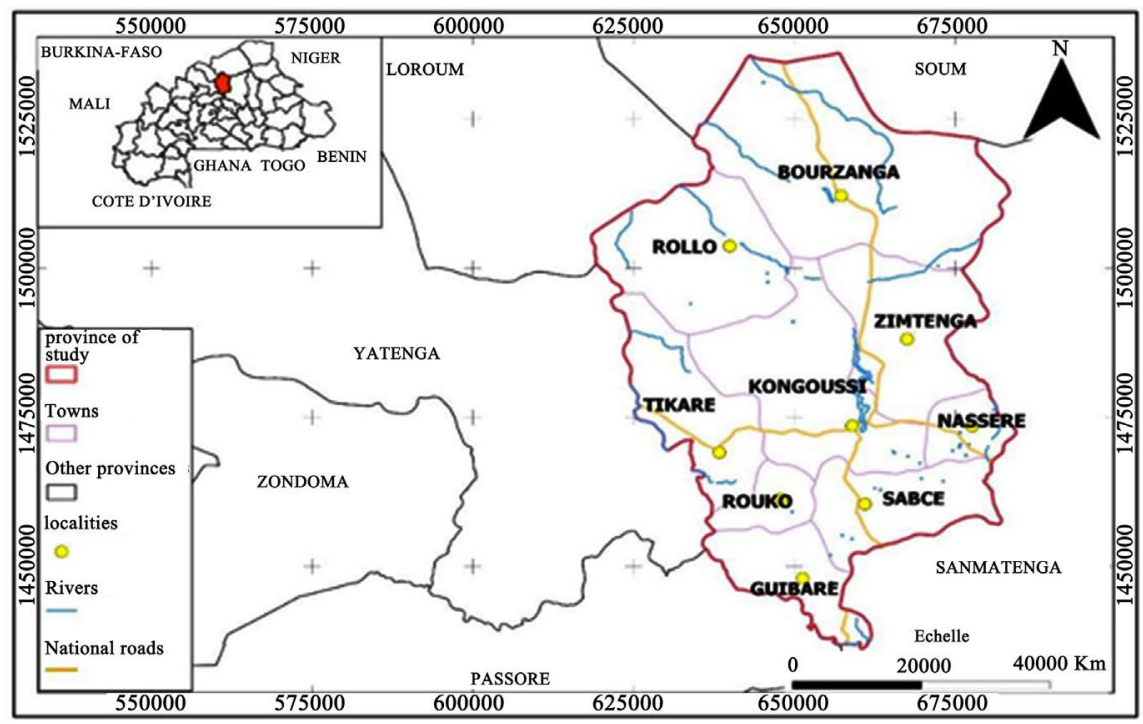

Figure 1. The geographical location of the study area. Sources: National Topographic database (institute of the geography of the country).

Above, the probit model was used for the analysis. Indeed, the objective of our study is to specify the behavior of the producers concerning the WSC technique by identifying the factors that influence its adoption, in the form of a probability [3] [14]. For the probit model, the estimate is made by the maximum likelihood method of the normal distribution. The theoretical model is based on the theory of technological innovation [2], the theory of technology acceptance (Davis I. et al., 1989), the theory of induced innovation. According to these theories, the factors influencing the adoption of technology are related to it according to a well-defined mathematical relation.

According to the theory of utility, technology will be adopted by the producer if the utility associated with this variety is greater than the old technology. The choice of the probit model is due among other things to the fact that it facilitates the manipulation of the results [1]. Indeed, Probit's distribution function in discrete choice modeling follows the normal centered distribution $[0,1][6]$.

\subsection{Econometric Model}

The analysis concerns WSC techniques. The decision to adopt technology is dichotomous where the producer can decide whether to use the technology. The adopter has been defined as a producer who uses at least one WSC technique. Non-adopters are those who use traditional techniques.

In this model, we define a variable $y^{*}$ as follows:

Let $y^{*}$ be the latent variable representing the producer's decision.

$$
Y^{*}=X_{i} \beta+\varepsilon_{i}
$$

With:

$\beta$ : the vector of the parameters to be estimated. 
$X_{i}:$ Represents the explanatory variables.

$\varepsilon_{i}$ : The terms of errors.

We have the following cases:

If $Y^{*}>0$ then the producer adopts the technology, so $y_{i}=1$

If $Y^{*} \leq 0$ then the producer does not adopt the technology, $y_{i}=0$

Consider the case where the producer adopts $\left(y_{i}=1\right)$. Then the probability $\mathrm{p}$ is given by:

$$
p\left(y_{i}=1\right) \text { means } p\left(Y^{*}>0\right)=p\left(X_{i} \beta+\varepsilon_{i}>0\right)=F\left(X_{i}^{*} \beta\right)
$$

And if $p\left(y_{i}=0\right)=1-F\left(X_{i}^{*} \beta\right)$ Then,

$$
p\left(y_{i}=1\right)=p\left(y_{i}^{*}>c\right)=1-p\left(\varepsilon_{i} \leq-X_{i}^{*} \beta\right)
$$

where $X_{i}^{*}$ is the difference of the component explanatory variables of the original vector $X_{i}$, unlike the constant term which now integrates the threshold " $c$ ". In this model, the probability that a producer chooses to adopt the WSC techniques is increasing for component variables of $X_{i}$ whose associated parameters are positive, and decreasing for those whose parameters are negative.

It is assumed that the errors $\left(\varepsilon_{i}\right)$ are independent and identically distributed and follow the normal distribution.

Theoretically we have the adoption of WSC techniques that can be written as a function of several variables and defined as follows:

$$
\begin{aligned}
\text { Adoption }= & \beta_{0}+\beta_{1} \hat{\mathrm{Acm}}+\beta_{2} \mathrm{Ni}+\beta_{3} \mathrm{Sc}+\beta_{4} \text { Agrou }+\beta_{5} \mathrm{Ap}+\beta_{6} \mathrm{Rco} \\
& +\beta_{7} \mathrm{Rf}+\beta_{8} \mathrm{Tg}+\beta_{9} \mathrm{Atec}+\beta_{10} \mathrm{PoTe}+\beta_{11} \mathrm{Psmt}+\beta_{12} \mathrm{Alpr} \\
& +\beta_{13} \mathrm{Psmt}+\beta_{14} \mathrm{Tmo}+\beta_{15} \mathrm{Ta}+\varepsilon
\end{aligned}
$$

The coefficients $\beta$ and $\varepsilon_{i}$ in the probit regression are estimated using the maximum likelihood method.

$$
\begin{gathered}
L(\beta)=\prod_{i=1}^{n}\left[F\left(X_{i}^{*} \beta\right)^{y_{i}}\left(1-F\left(X_{i}^{*} \beta\right)\right)^{1-y_{i}}\right] \\
\text { If } Y=1: L(\beta)=\prod_{i=1}^{n} F\left(X_{i}^{*} \beta\right) \text { and } \\
\text { If } Y=0: L(\beta)=\prod_{i=1}^{n}\left(1-F\left(X_{i}^{*} \beta\right)\right)
\end{gathered}
$$

With $F\left(X_{i}^{*} \beta\right)$ the density function of the reduced normal centered law, $p i$ the probability of adoption of WSC, $n_{1}$ and $n_{2}$ are respectively the numbers of adopting and non-adopting producers. Several factors may be behind the adoption of WSC techniques. These include socio-economic and institutional variables.

\section{Model Estimation}

\subsection{Interpretation of Results}

Table 1 shows that the model is significant at the $1 \%$ threshold as shown by the 
probability of Khi2 (Prob $>$ chi $2=0.0000)$, which shows the good specification of the model and that the variables selected make it possible to explain significantly the adoption of WSC techniques. The results of the econometric estimation indicate that six (6) variables significantly influence the adoption of WSC techniques. These variables are Early warning, Membership in a group, Technical assistance, Access to pesticides, Possession of a smartphone, Reviewed cotton. Among these variables, 4 positively influences the adoption, and 2 variables the negative influence.

Table 1. Results of Probit regression estimation.

\begin{tabular}{|c|c|c|c|}
\hline Adoption & $\mathrm{Z}$ & $\mathrm{P}>|\mathrm{Z}|$ & Marginal effects \\
\hline $\begin{array}{c}\text { Early } \\
\text { warning }\end{array}$ & $5.52 * * *$ & 0.000 & 0.0047517 \\
\hline $\begin{array}{l}\text { Membership } \\
\text { of a group }\end{array}$ & $3.54^{* * *}$ & 0.000 & 0.0061809 \\
\hline $\begin{array}{l}\text { Technical } \\
\text { assistance }\end{array}$ & $-2.63 * * *$ & 0.008 & -0.0083733 \\
\hline $\begin{array}{l}\text { Access to } \\
\text { the pesticide }\end{array}$ & $-2.57^{* * *}$ & 0.010 & -0.00632 \\
\hline $\begin{array}{l}\text { Type } \\
\text { of seed }\end{array}$ & -0.64 & 0.520 & -0.0005743 \\
\hline $\begin{array}{l}\text { Land } \\
\text { tenure }\end{array}$ & -0.91 & 0.363 & -0.0498277 \\
\hline $\begin{array}{l}\text { Animal } \\
\text { traction }\end{array}$ & 1.13 & 0.259 & 0.0679735 \\
\hline $\begin{array}{c}\text { Possession } \\
\text { of smartphone }\end{array}$ & $1.90 *$ & 0.058 & 0.004699 \\
\hline $\begin{array}{l}\text { Possession } \\
\text { of phone }\end{array}$ & 0.55 & 0.583 & 0.0496573 \\
\hline $\begin{array}{l}\text { Cotton } \\
\text { income }\end{array}$ & $2.31 * *$ & 0.021 & $8.38 \mathrm{e}-07$ \\
\hline $\begin{array}{l}\text { Cotton as the main } \\
\text { source of income }\end{array}$ & -0.67 & 0.505 & -0.0461258 \\
\hline $\begin{array}{c}\text { Level of } \\
\text { education }\end{array}$ & 0.14 & 0.887 & 0.0005284 \\
\hline $\begin{array}{l}\text { Cotton } \\
\text { area }\end{array}$ & -0.81 & 0.418 & -0.0374529 \\
\hline $\begin{array}{l}\text { Manpower } \\
\text { used }\end{array}$ & -0.86 & 0.390 & -0.002853 \\
\hline $\begin{array}{c}\text { Age of the head of } \\
\text { household }\end{array}$ & 0.64 & 0.520 & 0.0007589 \\
\hline \multicolumn{4}{|l|}{$\begin{array}{c}\text { Number of } \\
\text { observation }=369\end{array}$} \\
\hline \multirow{3}{*}{$\begin{array}{l}\text { Probit } \\
\text { regression }\end{array}$} & LR chi2 $(15)=56.90$ & & \\
\hline & Prob $>$ chi $2=0.0000$ & & \\
\hline & Pseudo R2 = 0.1116 & & \\
\hline
\end{tabular}

Source: Satat estimates results. Note: ${ }^{* *}$ Significant at the $1 \%$ threshold, ${ }^{*}$ Significant at the $5 \%$ threshold, * Significant at the $10 \%$ threshold. 


\section{- Overall suitability of the model}

The overall adequacy of the model is appreciated by the chi2 test. The adequacy of a model makes it possible to account for the relevance of the specified and estimated model. The likelihood ratio test of Likelihood Ratio (LR) uses the chi2 statistic, by setting $H 0$ : the coefficients associated with the explanatory variables are simultaneously zero and $H 1$ : at least one coefficient is different from zero. In this study, the probability associated with the static of chi2 is zero, we reject the null hypothesis. There is at least one decisive variable in the adoption of WSC techniques. The specified model is therefore adequate as a whole.

\section{- Socioeconomic determinants}

Cotton income: it positively influences the adoption of WSC techniques at the $5 \%$ level. This means that cotton income allows producers to finance development work and thus improve production to increase income. Marginal effects indicate that an increase in income from cotton of $1 \%$ increases the probability of adopting WSC techniques of 8.38e-07\%, all else being equal.

Variables such as educational level, cotton area, labor used, age of head of household, animal traction are not significant for the specific case of our study.

Possession of a smartphone: a variable measuring the level of wealth of the farmer, influences the adoption of the WSC techniques at the $10 \%$ threshold. This means that smartphones are the means of sharing a panoply of information on the most appropriate techniques, including WSC. The marginal effects result indicates that a $1 \%$ smartphone acquisition by producers increases the probability of adopting WSC techniques by $0.0047 \%$.

Technical Assistance: has a negative sign, and influences at the $1 \%$ threshold the adoption of WSC techniques, this means that in Bam, producers have free access to the technical assistance supported by the groups. But this assistance is not oriented towards the WSC techniques, the producers benefiting from the assistance in the WSC them even. Marginal effects indicate that a $1 \%$ increase in TA agent decreases the probability of adoption by $0.0084 \%$.

Access to pesticides: this variable has a negative sign, and influence at the $1 \%$ threshold the adoption of WSC techniques, this means that in Bam, cotton farmers adopting WSC techniques, do not use pesticides for cotton but rather for other cultures. Some of the money that can be used to develop the farm is used to buy pesticides. Marginal respondents indicate that producers' $1 \%$ access to pesticides decreases the probability of adopting WSC techniques by $0.0063 \%$.

\section{- Institutional determinants}

Membership in a group: positively influences the adoption of WSC techniques at $1 \%$. This means that membership in a group could potentially confer financial, material and labor benefits to members. Indeed, the WSC techniques require a financial investment and manpower. Marginal effects indicate that $1 \%$ of producer membership in a group increases the probability of adoption by $0.0062 \%$.

The existence of an early warning system: positively influences the adoption 
of the WSC techniques at $1 \%$. This means that having the information on the season allows the adoption of the WSC technique to cope with climatic drenching. This can be explained by the fact that lessons learned to play a great deal on the behavior of producers. Marginal effects indicate that a $1 \%$ increase in seasonal information acquisition for agriculture increases the likelihood of adopting WSC techniques by $0.0048 \%$, all other things being equal.

\subsection{Discussions and Economic Policies}

In light of the results obtained in the field about the influence of cotton income on the adoption of WSC techniques, these results confirm our hypothesis. The positive influence on the adoption of the WSC techniques of the Income variable is in line with those expected. This confirms the neoclassical theory that farmers adopt new technologies if they bring them net economic benefits [12] [15]. It is interesting to note the influence on the probability of adoption of WSC techniques, membership in a group. In other words, the financial burden of implementing these WSC techniques hurts the behavior of households faced with their adoption. But collective action acts positively because it is a method that requires a large workforce. These results are consistent with that collective action and the workforce are decisive factors in the adoption of technology [16]. To disseminate water and soil conservation techniques, not only in the Bam but also in the area, it will be necessary to take into account membership in a group as an instrument of economic policy. Thus, for a good extension, lightening the conditions for joining a group is essential [3] [7] [16]. Early warning, possession of a smartphone is determining factors in the adoption of WSC techniques. Thus, to get households to adopt WSC techniques, these households should be encouraged to have information about the season before starting it. These results confirm that, which states that environmental risks, wealth are factors influencing the choice of producers on technologies, [8] [13] [17] [18] for whom the behavior is downpouring. the risk of producers reduces the probability of adoption of new technologies in the study areas in Ethiopia. And finally, to make them understand the advantages and the constraints related to these techniques. Training sessions should be organized periodically (e.g. monthly) by agricultural and meteorological technicians assisted by those of research to provide households with detailed information on techniques improved by research and development. warning signs of the need for the adoption of WSC techniques. These training programs, even if they already exist, remain insufficient because some households adopt the WSC just by imitating their operating neighbors practicing the WSC after technical supervision received from a project for example.

In our work, technical assistance, and access to pesticides are variables that negatively influence the adoption of WSC techniques. These results disprove the one found in Kenya [16]. According to him, the contact with the agricultural agent makes the farmer favorable to the adoption of the technologies. Future actions should take into account the role of producer groups in the adoption of WSCs by cotton producers, with clusters at the interface between farmers and 
programs promoting and disseminating WSC techniques. Besides, a policy of favoritism may be considered with a view to bringing non-adopters to adoption. Thus, special facilities for access to agricultural equipment and credits may be given to the member of the groups, set up meteorological information cells of the producers.

\section{Conclusions}

Our study took place in the North-Central of Burkina Faso more precisely in the province of Bam, characterized by a significant degradation of the natural resources. The objective was to identify the socioeconomic and institutional determinants of the adoption of WSCs as a climate change adaptation technique by cotton farmers in Bam province. To achieve this objective, the use of the statistical and econometric analysis method was necessary. For the determinants of adoption, the probit model was chosen because it reflects both the use of quantitative and qualitative variables and is simple to use. The estimation of the parameters was done by the method of maximum likelihood. The data used in this research were obtained from a sample of three sixty-five (365) households, in the five communes of Bam (Guibare, Kongoussi, Rouko, Sabce, Tikare). These data come from the SARP Project Survey and the choice of households was exhaustive (all cotton producers).

Data analysis identified the variables that influence the adoption of water and soil conservation techniques. The choice to adopt or not the WSC techniques is influenced by socioeconomic and institutional factors.

Many authors have provided very enriching answers. The prices of factors of production and products are decisive factors in the adoption of WSC in Ethiopia. The production of traditional knowledge on anti-erosion measures is a determining factor in their adoption [13]. The ownership of property rights and collective action are real determinants of the adoption of WSC's [8]. The population and therefore the size of a household has a significant influence on the adoption of water and soil conservation technologies [5]. Through the econometric regression, in this study, the variables identified as having a significant impact on the probability of adoption of WSC techniques are Cotton income, Possession of a smartphone, Technical assistance, Access to pesticides, Membership in a group, the existence of an early warning system. Yields are also an instrument that can be used to assess behavior 56 households in the face of the adoption of WSCs in Bam. This adoption of WSC is similarly influenced by the perception of the utility that households derive from WSC.

\section{Conflicts of Interest}

The authors declare no conflicts of interest regarding the publication of this paper.

\section{References}

[1] Kinane, M.L., Kone, M. and Sidibe, A. (2008) Perception of Land Degradation and 
Adoption of Water and Soil Conservation Technologies in Northern Burkina Faso: The Case of Zaï and Pierreux Cordons. AgEcon Search, 543-546.

[2] Koutou, M., Ouédraogo, D., Nacro, H.B. and Lepage, M. (2007) Determinants of the Adoption of Zaï Forestier and Perspectives of Valorization of the Technique (Province of Yatenga, Burkina Faso). Acts of JSIRAUF, Hanoi, 6-9 November 2007, 6-9.

[3] Abdallah, A.-H., Michael, A. and Samuel, A.D. (2014) Smallholder Adoption of Soil and Water Conservation Techniques in Ghana. African Journal of Agricultural Research, 9, 539-546. https://doi.org/10.5897/AJAR2013.7952

[4] Iren, O.B., Akpan, J.F., Ediene, V.F. and Asanga, E.E. (2015) Influence of Cassava Peels and Poultry Manure-Based Compost on Soil Properties, Growth and Yield of Waterleaf ( Talinum triangulare Jacq) in an Ultisol of South-Eastern Nigeria. Journal of Soil Science and Environmental Management, 6, 140-147. https://doi.org/10.5897/JSSEM15.0486

[5] Gruenberg, B.D.A., Shelton, W., Rose, S.L. and Rutter, A.E. (2006) Factors Influencing Length of 15, No. 5, 195-202.

[6] Ouédraogo, S. and Millogo, M.C.S. (2007) Customary System of Land Tenure and Fight against Desertification in Rural Burkina Faso. Natures Sciences Sociétés, 15, 127-139. https://doi.org/10.1051/nss:2007038

[7] Dugué, P., Nana, P.D., Faure, G. and Le Gal, P.Y. (2015) Dynamics of Adoption of Conservation Agriculture in Family Farms: From Technology to Innovation Processes. Cahiers Agricultures, 24, 60-68. https://doi.org/10.1684/agr.2015.0748

[8] He, X.F., Cao, H. and Li, F.M. (2007) Econometric Analysis of the Determinants of Adoption of Rainwater Harvesting and Supplementary Irrigation Technology (RHSIT) in the Semiarid Loess Plateau of China. Agricultural Water Management, 89, 243-250. https://doi.org/10.1016/j.agwat.2007.01.006

[9] Paper, W., Papers, D., Uncertainty, P. and Papers, D. (1997) http://www.econstor.eu/

[10] Baidu-Forson, J. (1999) Factors Influencing Adoption of Land-Enhancing Technology in the Sahel: Lessons from a Case Study in Niger. Agricultural Economics, 20, 231-239. https://doi.org/10.1016/S0169-5150(99)00009-2

[11] Sidibé, A. (2005) Farm-Level Adoption of Soil and Water Conservation Techniques in Northern Burkina Faso. Agricultural Water Management, 71, 211-224. https://doi.org/10.1016/j.agwat.2004.09.002

[12] Bekele, W. and Drake, L. (2003) Soil and Water Conservation Decision Behavior of Subsistence Farmers in the Eastern Highlands of Ethiopia: A Case Study of the Hunde-Lafto Area. Ecological Economics, 46, 437-451. https://doi.org/10.1016/S0921-8009(03)00166-6

[13] Knowler, D. and Bradshaw, B. (2007) Farmers' Adoption of Conservation Agriculture: A Review and Synthesis of Recent Research. Food Policy, 32, 25-48. https://doi.org/10.1016/j.foodpol.2006.01.003

[14] Nkegbe, P., Shankar, B. and Ceddia, G. (2012) Smallholder Adoption of Soil and Water Conservation Practices in Northern Ghana. Conservation Practices in Northern Ghana.

[15] Abdulai, A. and Huffman, W. (2014) The Adoption and Impact of Soil and Water Conservation Technology: An Endogenous Switching Regression Application. Land Economics, 90, 26-43. https://doi.org/10.3368/le.90.1.26

[16] Nana, T.J. and Thiombiano, T. (2018) Adoption of Adaptation Strategies for Climate 
Change: Case of Burkina Faso Farmers. Journal of Agriculture and Environmental Sciences, 7, 53-65. https://doi.org/10.15640/jaes.v7n1a6

[17] Clay, D.C., et al. (1995) Promoting Food Security in Wranda through Sustainable Agricultural Productivity: Meeting the Challenges of Population Pressure, Land Degradation, and Poverty. MSU Int. Dev. Pap., 17.

[18] Nambiro, E. and Okoth, P. (2013) What Factors Influence the Adoption of Inorganic Fertilizer by Maize Farmers? A Case of Kakamega District, Western Kenya. Scientific Research and Essays, 8, 205-210. 